\title{
Bladder Tubulo-Cystic Clear Cell Adenocarcinoma
}

National Cancer Institute

\section{Source}

National Cancer Institute. Bladder Tubulo-Cystic Clear Cell Adenocarcinoma. NCI

Thesaurus. Code C39847.

A rare morphologic variant of bladder carcinoma characterized by the presence of malignant glandular epithelial cells and clear cells forming a tubulo-cystic pattern. 